\title{
UNDERSTANDING THE MECHANISM OF ACTION OF INTRAVENOUS IMMUNOGLOBULINS: A TEN YEARS EXPERIENCE IN TREATING GUILLAIN BARRÉ SYNDROME
}

\author{
ADINA STOIAN ${ }^{1,4}$, ANCA MOTATAIANU $^{2,4 *}$, LAURA BARCUTEAN $^{2,4}$, SMARANDA MAIER $^{2,4}$, \\ ZOLTAN BAJKO $^{2,4}$, SEPTIMIU VOIDAZAN ${ }^{3}$, ANDRADA FARCAS ${ }^{4}$, RODICA BALASA $^{2,4}$ \\ ${ }^{1}$ Department of Pathophysiology, University of Medicine, Pharmacy, Sciences and Technology "George Emil Palade” Târgu \\ Mures, Romania \\ ${ }^{2}$ Department of Neurology, University of Medicine, Pharmacy, Sciences and Technology “George Emil Palade” Târgu \\ Mureş, Romania \\ ${ }^{3}$ Department of Epidemiology, University of Medicine, Pharmacy, Sciences and Technology "George Emil Palade” Târgu \\ Mureş, Romania \\ ${ }^{4}$ Neurology 1 Clinic, Emergency Clinical County Hospital of Târgu Mureş, Romania
}

*corresponding author: motataianuanca@gmail.com

Manuscript received: October 2019

\begin{abstract}
Guillain Barré syndrome is an acute immune-mediated, heterogeneous disease that affects the peripheral nervous system and is characterized by rapidly progressive motor deficit, diminished reflexes, cranial nerve involvement, respiratory failure, sometimes with involvement of autonomic nervous system which contribute to the mortality rate. Both T-cells and B-cells are involved in its pathogenesis, finally leading to myelin destruction or axonal damage. The present paper underlines the effect of intravenous immunoglobulins in treating this disease by discussing the pathophysiology of Guillain Barré syndrome with the participation of immune system and the mechanism of action of intravenous immunoglobulins with the reduction of autoantibodies, down regulation of macrophage activity, reduction of inflammatory cytokine levels and cell adhesion molecules thus limiting the self-harm and the passage of autoimmune cells through the blood-nerve barrier.
\end{abstract}

\section{Rezumat}

Sindromul Guillain Barré este o boală heterogenă, imun-mediată care afectează sistemul nervos periferic și se caracterizează prin deficit motor rapid progresiv, reflexe osteotendinoase diminuate, afectare de nervi cranieni, uneori cu insuficiență respiratorie și afectare de sistem nervos autonom care contribuie la creșterea ratei de mortalitate. Atât limfocitele T cât și limfocitele B sunt implicate în patogeneză conducând în cele din urmă la distrucția mielinei sau la afectare axonală. Lucrarea de față subliniază rolul imunoglobulinelor intravenoase în tratamentul acestei boli, prezentând fiziopatologia sindromului Guillain Barré, care implică participarea sistemului imun și mecanismul de acțiune al imunoglobulinelor administrate intravenos, care au rol în reducerea titrului de autoanticorpi, reducerea activării macrofagelor, a nivelului citokinelor inflamatorii și a moleculelor de adeziune celulară, limitând astfel autoagresiunea și pasajul celulelor implicate în imunitate prin bariera sânge-nerv.

Keywords: intravenous immunoglobulins, Guillain Barré Syndrome, inflammatory cytokine levels

\section{Introduction}

Guillain Barré syndrome (GBS) is an acute onset, immune-mediated, heterogeneous disease that affects the peripheral nervous system and is characterized by rapidly progressive motor deficit of the legs and arms. This can occur both with or without sensory disturbances like paraesthesia and numbness, diminished reflexes or areflexia $[4,50]$. Cranial nerve involvement with eyelid ptosis, facial or pharyngeal weakness may also occur in a number of cases and $25 \%$ of patients develop respiratory failure as a result of the neuromuscular paralysis and diaphragmatic weakness which is caused by phrenic nerve involvement. In such cases, they will require mechanical ventilation, and there is a mortality rate of $4-15 \%[7,18]$. The involvement of autonomic nervous system is manifested through cardiac arrhythmias, blood pressure instability, and gastrointestinal dysmotility, all of which contribute to the mortality rate $[30,48]$.

The most common subtypes of GBS are acute inflammatory demyelinating polyradiculoneuropathy (AIDP), which accounts for $90 \%$ of the cases in North America and Europe and the axonal variants, acute motor axonal neuropathy (AMAN), and acute motor-sensory neuronopathy (AMSAN), which accounts for $30 \%$ to $47 \%$ of cases in South and Central America and Asia [7, 23]. Indeed, the Miller Fisher syndrome is a less common variant of GBS which is characterized 
by cranial nerve involvement with ophthalmoplegia, ataxia, and areflexia [49].

It seems to be preceded by different infections within the last months in $60-70 \%$ of cases and has a rapid evolution towards aggravation in days, indicating the rapidly progressive process [36].

The annual reported incidence ranges from 0.81 1.89 per 100.000 person-years, based on the study published by B. Van Den Berg in 2014 [49], to 1.3 4.0 per 100.000 people per year in another study published by J. Ray Chauduri in the same year [7]. However, both studies show that men are approximately 1.5 times more affected than women [7, 49]. A low rate of 0.4 per 100.000 person-years was reported in Brazil [41] and a temporary increase in incidences was reported in China in 1991 - 1992 in a rural area [19]. Recently, an outbreak of GBS was also associated with Zika virus in French Polynesia [5].

Diagnosis is based on the character's clinical history and neurological examination. Corticospinal fluid (CSF) examination should be performed at the initial evaluation of the patient to rule out other causes of muscle weakness. Indeed, the presence of the disease may show increased protein levels in the presence of a normal CSF cell count (albumino-cytological dissociation) $[13,30]$. However, the level of CSF proteins may be normal in the first week after the disease's onset in $30-50 \%$ of patients and remains normal in $10-30 \%$ of patients until two weeks after onset. As such, the normal protein level in the CSF does not exclude the diagnosis of GBS [11, 13, 30]. Furthermore, the presence of increased pleocytosis could also suggest other pathologies, such as carcinomatous meningitis or infective disease of the spinal cord or nerve roots $[11,30]$ and other lab test may also be necessary [3].

Nerve conduction studies are an extremely useful tool in supporting the diagnosis, especially if there is an atypical clinical presentation and there is a need to differentiate between demyelinating and axonal polyradiculoneuritis [30].

\section{Materials and Methods}

\section{Study design}

We conducted a case-control retrospective study in which we reviewed the medical data recorded for patients admitted with GBS in the First Neurology Clinic of Târgu Mureș County Emergency Hospital, Romania, between January 2009 and December 2018. They were diagnosed by the treating physician based on their clinical evolution and symptoms, neurological examination, nerve conduction studies and lumbar puncture with CSF analysis. A total number of 137 patients were evaluated and we excluded patients with previous diseases that led to paresis, along with patients who underwent therapeutic plasma exchange or a combination of treatments: intravenous immuno- globulins (IVIg) and corticosteroids, IVIg and therapeutic plasma exchange or therapeutic plasma exchange combined with corticosteroids. We included 100 patients over the age of 18 years old in our study. These individuals provided consent to use their medical records and had received either corticosteroids or IVIg treatment. We then formed two groups to compare them for the study.

Study procedure

Data collected included basic demographics (age, sex), history of previous GBS triggers (infections, surgical procedures, vaccination), number of days from the onset of symptoms to admission, length of hospitalization, associated comorbidities (hypertension, diabetes mellitus), cranial nerve involvement, autonomic nervous system involvement, phenotypic variant of GBS (AIDP, AMAN, ASMAN, Miller Fisher syndrome), presence of respiratory insufficiency and the need for mechanical ventilation, laboratory investigations regarding CSF, treatment received, complications caused by infections and the outcome. The motor deficit was assessed by the Medical Research Council sum score, and this includes power evaluation for upper limbs (deltoid, biceps, wrist extensor bilateral) and for lower limbs (iliopsoas, quadriceps and tibialis anterior bilateral) at admission and at discharge, with a maximum score of 60 .

\section{Statistical analysis}

Statistical analysis was performed using SPSS for Windows version 22.0 (SPSS, Inc., Chicago, IL, USA). Data were considered as nominal or quantitative variables, and nominal variables were characterized using frequencies. Quantitative variables were tested for normality of distribution using Kolmogorov-Smirnov test and were characterized by median and percentiles $(25-75 \%)$ or by the mean and standard deviation (SD) where appropriate. A chi-square test was used in order to compare the frequencies of the nominal variables. Quantitative variables were compared using the t-test, Mann-Whitney test, ANOVA test or KruskalWallis test, when appropriate. The correlation between the quantitative variables was assessed using Spearman's rho when appropriate, and the level of statistical significance was set at $\mathrm{p}<0.05$.

Ethical considerations

Ethical approval was obtained from the Ethics Committee of the Clinical Emergency County Hospital from Târgu Mureș, Romania. The study was also conducted according to the principles of the Helsinki Declaration.

\section{Results and Discussion}

Characteristics of all patients from our study are summarized in Table I. The median age of our patients was $55.9 \pm 16.1$ and the majority were male $(61 \%)$. The most common symptoms presented at admission were motor deficits (mean MRC sum score 42.1 \pm 12.3 ) 
FARMACIA, 2020, Vol. 68, 3

with a slight improvement at discharge (mean MRC sum score $48.5 \pm 10.1$ ), cranial nerve involvement (24\%). The most common complications were autonomic nervous system involvement (29\%), and respiratory failure $(7 \%)$ with the need for mechanical ventilation $(6 \%)$. Possible etiological factors (previous infections, surgical procedures, previous vaccination) were found in $52 \%$ of the cases. Distribution on GBS phenotypic variants included AIDP (77\%), AMAN (6\%), ASMAN (15\%), Miller Fisher syndrome (2\%). Median time from onset of symptoms to admission was 7 days (0 60) and the average length of hospitalization was 11 days (3 - 110). Death occurred in 3\% of the cases.

Table I

General characteristics of all patients

\begin{tabular}{|c|c|c|}
\hline \multirow{2}{*}{\multicolumn{2}{|c|}{ Age (years); Mean \pm SD }} & \\
\hline & & $55.9 \pm 16.1$ \\
\hline \multicolumn{2}{|l|}{ Sex; Male (\%) } & $61(61 \%)$ \\
\hline \multicolumn{2}{|c|}{ Time from onset to admission; Median (min - max) } & $7(0-60)$ \\
\hline \multicolumn{2}{|c|}{ Length of hospitalization; Median (min - max) } & $11(3-110)$ \\
\hline \multicolumn{2}{|l|}{ MRC sum score at admission; Mean \pm SD } & $42.1 \pm 12.3$ \\
\hline \multicolumn{2}{|l|}{ MRC sum score at discharge; Mean \pm SD } & $48.5 \pm 10.1$ \\
\hline \multicolumn{2}{|l|}{ Cranial nerves involvement $(\%)$} & $24(24 \%)$ \\
\hline \multicolumn{2}{|l|}{ Autonomic nervous system involvement (\%) } & $29(29 \%)$ \\
\hline \multicolumn{2}{|l|}{ CSF - protein level; Median (min - max) } & $550(330-3141)$ \\
\hline \multicolumn{2}{|l|}{ CSF - leucocytes; Median (min - max) } & $4(0-24)$ \\
\hline GBS phenotype no $(\%)$ & $\begin{array}{l}\text { AIDP } \\
\text { AMAN } \\
\text { ASMAN } \\
\text { Miller Fisher }\end{array}$ & $\begin{aligned} 77 & (77 \%) \\
6 & (6 \%) \\
15 & (15 \%) \\
2 & (2 \%)\end{aligned}$ \\
\hline \multicolumn{2}{|l|}{ Respiratory insufficiency $(\%)$} & $7(7 \%)$ \\
\hline \multicolumn{2}{|l|}{ Mechanical ventilation $(\%)$} & $6(6 \%)$ \\
\hline Presence of possible triggers of GBS (\%) & $\begin{array}{l}0 \\
\text { Previous infections (respiratory tract and digestive) } \\
\text { Surgical procedures } \\
\text { Previous vaccination }\end{array}$ & $\begin{array}{c}48(48 \%) \\
46(46 \%) \\
3(3 \%) \\
3(3 \%)\end{array}$ \\
\hline \multicolumn{2}{|l|}{ Essential hypertension (\%) } & $66(66 \%)$ \\
\hline \multicolumn{2}{|l|}{ Diabetes mellitus (\%) } & $22(22 \%)$ \\
\hline \multicolumn{2}{|l|}{ GPT value; Median (min - max) } & $35(9.1-603.0)$ \\
\hline \multicolumn{2}{|l|}{ GOT value; Median (min - max) } & $27.1(10.6-526.0)$ \\
\hline \multicolumn{2}{|l|}{ Na value; Mean SD } & $138.6 \pm 4.14$ \\
\hline \multicolumn{2}{|l|}{ Death; Number (\%) } & $3(3 \%)$ \\
\hline
\end{tabular}

Table II

Phenotype distribution of all patients (with and without IVIg treatment)

\begin{tabular}{|l|c|c|c|c|c|}
\hline \multicolumn{1}{|c|}{ Variable } & AIDP & AMAN & ASMAN & Miller Fisher & p \\
\hline Sex; Male (\%) & $50(64.9 \%)$ & $3(50.0 \%)$ & $7(46.7 \%)$ & $1(50.0 \%)$ & $0.57^{*}$ \\
\hline Cranial nerves involvement (\%) & $16(20.8 \%)$ & $2(33.3 \%)$ & $4(26.7 \%)$ & $2(100 \%)$ & $0.074^{*}$ \\
\hline $\begin{array}{l}\text { Autonomic nervous system involvement } \\
(\%)\end{array}$ & $18(23.4 \%)$ & $\mathbf{4 ( 6 6 . 7 \% )}$ & $7(46.7 \%)$ & - & $\mathbf{0 . 0 3}^{*}$ \\
\hline Respiratory insufficiency (\%) & $2(2.6 \%)$ & $\mathbf{2 ( 3 3 . 3 \% )}$ & $3(20 \%)$ & - & $\mathbf{0 . 0 1 7} *$ \\
\hline Mechanical ventilation (\%) & $1(1.3 \%)$ & $2(33.3 \%)$ & $3(20 \%)$ & $0(0 \%)$ & $\mathbf{0 . 0 1 1} *$ \\
\hline Essential hypertension (\%) & $49(63.6 \%)$ & $3(50 \%)$ & $12(80 \%)$ & $2(100 \%)$ & $0.38^{*}$ \\
\hline Diabetes mellitus (\%) & $16(20.8 \%)$ & $1(16.7 \%)$ & $4(26.7 \%)$ & $1(50 \%)$ & $0.79^{*}$ \\
\hline Death (\%) & $1(1.3 \%)$ & $0(0 \%)$ & $2(13.3 \%)$ & $0(0 \%)$ & $0.12^{*}$ \\
\hline Age; Min \pm SD & $54.75 \pm 16.73$ & $53.00 \pm 18.74$ & $62.87 \pm 10.33$ & - & $0.19^{* *}$ \\
\hline $\begin{array}{l}\text { Time from onset to admission; Median } \\
\text { (min - max) }\end{array}$ & $7(1-60)$ & $11.5(6-60)$ & $12(0-60)$ & - & $0.15^{* * *}$ \\
\hline CSF - protein level ; Median (min - max) & $542(330-3141)$ & $710(450-860)$ & $655(450-907.0)$ & - & $0.38^{* * *}$ \\
\hline CSF - leucocytes; Median (min - max) & $4(1-24)$ & $2.5(0-5)$ & $4(1-10)$ & - & $0.27^{* * *}$ \\
\hline $\begin{array}{l}\text { MRC sum score at admission; Median } \\
\text { (min - max) }\end{array}$ & $42.14 \pm 11.73$ & $35.4 \pm 20.61$ & $41.83 \pm 11.46$ & - & $0.86^{* * *}$ \\
\hline $\begin{array}{l}\text { MRC sum score at discharge; Median } \\
\text { (min - max) }\end{array}$ & $48.52 \pm 9.79$ & $45.0 \pm 17.26$ & $48.08 \pm 9.46$ & - & $0.86^{* *}$ \\
\hline $\begin{array}{l}\text { Length of hospitalization; Median (min - } \\
\text { max) }\end{array}$ & $11(3-30)$ & $18(7-110)$ & $11(5-26)$ & - & $0.22^{* * * *}$ \\
\hline
\end{tabular}

* Chi square test, ** ANOVA test, *** Kruskal Wallis test 
Table II presents the phenotypic variants of GBS and their correlations with the factors mentioned above. We found that the autonomic nervous system involvement is more frequent in patients with AMAN phenotype $(p=0.03)$. Similarly, in the case of AMAN, phenotype respiratory failure is more frequent $(p=0.017)$ and this included the need for mechanical ventilation. In Table III, we have a comparative analysis between the group of patients who received IVIg and patients treated with corticosteroids. We found by applying the student test that the mean age was higher in the group treated with corticosteroids when compared with the patients treated with IVIg $(p=0.013)$. This was also compared with the MRC sum score at admission and at discharge and was higher in corticosteroids treated patients $(\mathrm{p}=0.001$, respectively $\mathrm{p}=0.002)$.

\begin{tabular}{|c|c|c|c|c|}
\hline & Variable & $\begin{array}{c}\text { Patients receiving } \\
\text { IVIg }\end{array}$ & $\begin{array}{l}\text { Patients receiving } \\
\text { corticosteroids }\end{array}$ & $\mathrm{p}$ \\
\hline Age; mean \pm SD & & $52.84 \pm 14.91$ & $59.82 \pm 16.68$ & $0.013 * *$ \\
\hline Time from onset to adn & hission; median (min - max) & $7(0-60)$ & $8(1-60)$ & $0.11^{* * *}$ \\
\hline CSF - elevated protein & level; median (min - max) & $655(330-3141)$ & $453(450-850)$ & $0.03 * * *$ \\
\hline CSF - leucocytes; medi & an $(\min -\max )$ & $4(0-24)$ & $4(1-7)$ & $0.4 * * *$ \\
\hline MRC sum score at adm & ission; mean $\pm \mathrm{SD}$ & $36.8 \pm 12.59$ & $48.16 \pm 8.86$ & $0.001 * *$ \\
\hline MRC sum score at disc & harge; mean \pm SD & $45.45 \pm 11.73$ & $52.0 \pm 6.54$ & $0.002 * *$ \\
\hline Length of hospitalizatic & n; median $(\min -\max )$ & $13(5-110)$ & $11(3-30)$ & $0.81 * * *$ \\
\hline Sex, Male $(\%)$ & & $33(60.0)$ & $45.9(62.2)$ & $0.82 *$ \\
\hline Cranial nerve involvem & ent; no (\%) & $18(32.7)$ & $6(13.3)$ & 0.034* \\
\hline Autonomic nervous sys & tem involvement; no (\%) & $25(45.5)$ & $4(8.9)$ & 0.001* \\
\hline Miller Fisher syndrome & no $(\%)$ & $2(3.6)$ & $0(0)$ & $0.19 *$ \\
\hline Respiratory insufficien & y; no (\%) & $7(12.7)$ & $0(0)$ & 0.016* \\
\hline Mechanical ventilation & no $(\%)$ & $6(10.9)$ & $0(0)$ & $0.031 *$ \\
\hline Essential hypertension; & no $(\%)$ & $34(61.8)$ & $32(71.1)$ & $0.39 *$ \\
\hline Diabetes mellitus; no ( & & $15(27.3)$ & $7(15.6)$ & $0.22 *$ \\
\hline Death $(\%)$ & & $3(5.5)$ & $0(0)$ & $0.25^{*}$ \\
\hline $\begin{array}{l}\text { Guillain Barré } \\
\text { phenotype; no }(\%)\end{array}$ & $\begin{array}{l}\text { AIDP } \\
\text { AMAN } \\
\text { ASMAN } \\
\text { Miller Fisher }\end{array}$ & $\begin{array}{l}39(70.9) \\
3(5.5) \\
11(20) \\
2(100)\end{array}$ & $\begin{array}{c}38(84.4) \\
3(6.7) \\
4(8.9) \\
0(0)\end{array}$ & $0.25^{*}$ \\
\hline $\begin{array}{l}\text { Etiological factors; no } \\
(\%)\end{array}$ & $\begin{array}{l}\text { Previous infections (respiratory tract and digestive) } \\
\text { Surgical procedures } \\
\text { Previous vaccination }\end{array}$ & $\begin{array}{l}30(54.5) \\
1(1.8) \\
3(5.5)\end{array}$ & $\begin{array}{c}16(35.6) \\
2(4.4) \\
0(0)\end{array}$ & $0.04 *$ \\
\hline
\end{tabular}

* Chi square test, ** Student test, *** Mann Whitney test

By applying the non-parametric test, Mann-Whitney significant differences were observed between the CSF level of proteins and the median values being higher for the IVIg group $(p=0.03)$. For the quantitative variables, the chi-square test was used and significant correlations were found between cranial nerve involvement being higher in the group treated with IVIg $(p=0.034)$, autonomic nervous system involvement more frequently in the group treated with IVIg $(p=0.001)$, respiratory failure and the need for mechanical ventilation was more frequently in the IVIg treated group of patients $(p=0.016$, respectively $\mathrm{p}=0.031$ ), and the etiological factors were more commonly identified as preceding GBS in the IVIg treated group of patients $(\mathrm{p}=0.04)$.

In Table IV, we have the analysis of the MRC sum score mean values at admission and at discharge for all the patients admitted with GBS. After applying the Student test, the MRC sum score was statistically significantly higher at discharge in the absence of cranial nerve involvement $(\mathrm{p}=0.034)$. Furthermore, the MRC sum score mean values at admission are lower if there was respiratory failure $(p=0.001)$ and need for mechanical ventilation $(\mathrm{p}=0.001)$, and the same is true for the MRC sum score at discharge $(\mathrm{p}=0.0001$, respectively $\mathrm{p}=0.001)$.

In Table V, we have the analysis of the MRC sum score mean values at admission and at discharge for patients admitted with GBS and received IVIg treatment. After applying the Student test, MRC sum score is found to be statistically significantly higher at admission and at discharge in the absence of respiratory insufficiency $(\mathrm{p}=0.01$, respectively $\mathrm{p}=0.001)$ and when the mechanical ventilation was not needed $(\mathrm{p}=0.009$, respectively 0.0001). 
FARMACIA, 2020, Vol. 68, 3

Table IV

MRC sum score at admission and at discharge for all the patients

\begin{tabular}{|c|c|c|c|c|}
\hline \multicolumn{2}{|l|}{ Variable } & \multirow{2}{*}{$\begin{array}{c}\begin{array}{c}\text { MRC sum score } \\
\text { at admission }\end{array} \\
42.13 \pm 12.3\end{array}$} & \multirow{2}{*}{$\begin{array}{c}\text { MRC sum score } \\
\text { at discharge } \\
48.52 \pm 10.15\end{array}$} & \multirow{2}{*}{$\begin{array}{c}\mathrm{p} \\
\mathbf{0 . 0 0 0 1}\end{array}$} \\
\hline All the patients & MRC; Mean \pm SD & & & \\
\hline \multirow{2}{*}{$\begin{array}{c}\text { Sex; } \\
\text { Mean } \pm \text { SD }\end{array}$} & $\mathrm{M}$ & $43.10 \pm 12.64$ & $49.25 \pm 10.32$ & \multirow{2}{*}{$0.33 * / 0.37 * *$} \\
\hline & $\mathrm{F}$ & $40.57 \pm 11.83$ & $47.35 \pm 9.89$ & \\
\hline \multirow{2}{*}{$\begin{array}{c}\text { Cranial nerve involvement; } \\
\text { Mean } \pm \text { SD }\end{array}$} & Yes & $38.05 \pm 16.48$ & $44.38 \pm 14.85$ & \multirow{2}{*}{$0.087 * / \mathbf{0 . 0 3 4} * *$} \\
\hline & No & $43.27 \pm 10.76$ & $49.68 \pm 8.15$ & \\
\hline \multirow{2}{*}{$\begin{array}{c}\text { Respiratory insufficiency; } \\
\text { Mean } \pm \text { SD }\end{array}$} & Yes & $19.67 \pm 8.96$ & $22.33 \pm 13.57$ & \multirow{2}{*}{$0.001 * / 0.0001 * *$} \\
\hline & No & $42.85 \pm 11.76$ & $49.37 \pm 8.9$ & \\
\hline \multirow{2}{*}{$\begin{array}{c}\text { Mechanical ventilation; } \\
\text { Mean } \pm \text { SD }\end{array}$} & Yes & $14.5 \pm 0.7$ & $14.5 \pm 0.7$ & \multirow{2}{*}{$0.001 * / 0.001 * *$} \\
\hline & No & $42.71 \pm 11.77$ & $49.24 \pm 8.93$ & \\
\hline \multirow{2}{*}{$\begin{array}{l}\text { Presence of possible triggers of GBS; } \\
\text { Mean } \pm \text { SD }\end{array}$} & Yes & $40.05 \pm 13.09$ & $47.91 \pm 9.63$ & \multirow{2}{*}{$\mathbf{0 . 1 0} * / 0.44 * *$} \\
\hline & No & $44.25 \pm 11.36$ & $49.5 \pm 10.13$ & \\
\hline \multirow{2}{*}{$\begin{array}{c}\text { Essential hypertension; } \\
\text { Mean } \pm \text { SD } \\
\end{array}$} & Yes & $41.83 \pm 12.22$ & $47.51 \pm 10.62$ & \multirow{2}{*}{$0.74 * / 0.17 * *$} \\
\hline & No & $42.7 \pm 12.71$ & $50.45 \pm 9.02$ & \\
\hline \multirow{2}{*}{$\begin{array}{l}\text { Diabetes mellitus; } \\
\text { Mean } \pm \text { SD }\end{array}$} & Yes & $38.32 \pm 15.04$ & $43.77 \pm 14.81$ & \multirow{2}{*}{$0.16^{*} / 0.07 * *$} \\
\hline & No & $43.26 \pm 11.28$ & $49.93 \pm 7.88$ & \\
\hline
\end{tabular}

* $\mathrm{p}$ value for MRC sum score at admission/** $\mathrm{p}$ value for MRC sum score at discharge

Table V

MRC sum score at admission and at discharge for the patients receiving IVIg

\begin{tabular}{|c|c|c|c|c|}
\hline \multicolumn{2}{|c|}{ Variable } & \multirow{2}{*}{$\begin{array}{l}\text { MRC sum score } \\
\text { at admission } \\
36.8 \pm 12.59\end{array}$} & \multirow{2}{*}{$\begin{array}{l}\text { MRC sum score } \\
\text { at discharge } \\
45.45 \pm 11.73\end{array}$} & \multirow{2}{*}{$\begin{array}{c}\mathrm{p} \\
\mathbf{0 . 0 0 0 1}\end{array}$} \\
\hline Patients receiving IVIg & MRC sum score; Mean \pm SD & & & \\
\hline \multirow{2}{*}{$\begin{array}{c}\text { Sex; } \\
\text { Mean } \pm \text { SD }\end{array}$} & $\mathrm{M}$ & $38.45 \pm 13.43$ & $46.74 \pm 12.17$ & \multirow{2}{*}{$0.24 * / 0.33 * *$} \\
\hline & $\mathrm{F}$ & $34.25 \pm 10.97$ & $43.45 \pm 11.0$ & \\
\hline \multirow{2}{*}{$\begin{array}{c}\text { Cranial nerve involvement; } \\
\text { Mean } \pm \text { SD }\end{array}$} & Yes & $35.40 \pm 15.79$ & $42.67 \pm 15.47$ & \multirow{2}{*}{$0.61 * / 0.27 * *$} \\
\hline & No & $37.39 \pm 11.19$ & $46.61 \pm 9.80$ & \\
\hline \multirow{2}{*}{$\begin{array}{c}\text { Respiratory insufficiency; } \\
\text { Mean } \pm \text { SD }\end{array}$} & Yes & $19.67 \pm 8.96$ & $22.33 \pm 13.57$ & \multirow{2}{*}{$0.01 * / 0.001 * *$} \\
\hline & No & $37.88 \pm 12.04$ & $46.9 \pm 10.11$ & \\
\hline \multirow{2}{*}{$\begin{array}{c}\text { Mechanical ventilation; } \\
\text { Mean } \pm \text { SD }\end{array}$} & Yes & $14.5 \pm 0.7$ & $14.5 \pm 0.7$ & \multirow{2}{*}{$0.009 * / 0.0001 * *$} \\
\hline & No & $37.71 \pm 11.97$ & $46.71 \pm 10.09$ & \\
\hline \multirow{2}{*}{$\begin{array}{c}\text { Essential hypertension; } \\
\text { Mean } \pm \text { SD }\end{array}$} & Yes & $36.68 \pm 12.68$ & $43.94 \pm 12.37$ & \multirow{2}{*}{$0.93 * / 0.25 * *$} \\
\hline & No & $37.00 \pm 12.75$ & $47.8 \pm 10.52$ & \\
\hline \multirow{2}{*}{$\begin{array}{l}\text { Diabetes mellitus; } \\
\text { Mean } \pm \text { SD }\end{array}$} & Yes & $35.40 \pm 14.62$ & $41.27 \pm 15.85$ & \multirow{2}{*}{$0.61 * / 0.10 * *$} \\
\hline & No & $37.39 \pm 11.81$ & $47.19 \pm 9.24$ & \\
\hline \multirow{2}{*}{$\begin{array}{c}\text { Obesity; } \\
\text { Mean } \pm \text { SD }\end{array}$} & Yes & $42.22 \pm 12.66$ & $45.33 \pm 13.22$ & \multirow{2}{*}{$0.25 * / 0.97 * *$} \\
\hline & No & $35.86 \pm 12.51$ & $45.48 \pm 11.56$ & \\
\hline \multirow{2}{*}{$\begin{array}{l}\text { Cardiac diseases; } \\
\text { Mean } \pm \text { SD }\end{array}$} & Yes & $36.35 \pm 11.58$ & $43.20 \pm 11.41$ & \multirow{2}{*}{$0.83 * / 0.27 * *$} \\
\hline & No & $37.10 \pm 13.37$ & $46.9 \pm 11.88$ & \\
\hline \multirow{2}{*}{$\begin{array}{l}\text { Complications caused by } \\
\text { infections; Mean } \pm \text { SD }\end{array}$} & Yes & $31.29 \pm 13.39$ & $38.86 \pm 13.70$ & \multirow{2}{*}{$0.007 * / 0.002 * *$} \\
\hline & No & $40.67 \pm 10.57$ & $50.07 \pm 7.36$ & \\
\hline
\end{tabular}

$* \mathrm{p}$ value for MRC sum score at admission/** $\mathrm{p}$ value for MRC sum score at discharge

Also, the MRC sum score values at admission were higher if there were no superimposed infections $(\mathrm{p}=0.007)$ and the same is true for the MRC sum score at discharge $(p=0.002)$. By applying correlations with the non-parametric Spearman test between MRC sum score at admission and at discharge for all the patients with age, time from onset of symptoms to admission, presence of increased protein level in $\mathrm{CSF}$ and the length of hospitalization, an inverse correlation was observed (rho $=-0.247 \mathrm{MRC}$ sum score at admission $/$ rho $=-0.253 \mathrm{MRC}$ sum score at discharge) and this was found to be only statistically significant ( $p=0.016 \mathrm{MRC}$ sum score at admission/ $\mathrm{p}=0.013$ MRC sum score at discharge) with the length of hospitalization.

By applying the correlations with the non-parametric Spearman test only for the patients receiving IVIg treatment between the MRC sum score at admission and at discharge with age, time from onset of symptoms to admission, presence of increased protein level in CSF and the length of hospitalization, an inverse correlation was observed (rho $=-0.296$ MRC sum score at admission) and was found to be statistically significant ( $\mathrm{p}=0.037 \mathrm{MRC}$ sum score at admission) only with the length of hospitalization, with its duration being lower if the MRC sum score was higher at admission. 
Different types of infectious disorders have been reported to precede the onset of Guillain Barré syndrome in the literature, with the most frequent being respiratory or digestive tract infections. Other etiological factors incriminated were influenza and rabies vaccination or other stressful events like surgical procedures [32, 44, 49, 53]. Pathogens that are most commonly involved are Campilobacter jejuni, Mycoplasma pneumoniae, Haemophilus influenzae, Cytomegalovirus, Epstein Barr virus, and the Zika virus [5, 28, 36, 49]. The occurrence of GBS is due to a mixture between the host and microbial factors based on their interaction and not all individuals who pass through infections develop GBS. GBS is an immune-mediated disorder in which both T-cells and B-cells are involved and an important step in its pathogenesis is the activation of $\mathrm{T}$ lymphocytes and autoreactive antibodies synthesis [28]. Antigen presenting cells (ACP) can be macrophages or dendritic cells and process the antigen that is commonly represented by lipo-oligosaccharides (LOSs) from the bacterial wall and present it to autoreactive $\mathrm{T}$ cells. This leads to local and systemic activation of $\mathrm{T}$ cells with increased production of cytokines, TNFalfa (tumour necrosis factor), interferons and interleukins that increase the permeability of the bloodnerve barrier. T cells can activate B lymphocyte into plasma cells via TNF, interferon, and cytokines like IL-4 (interleukin) and IL-6 with increased production of antibodies that cross-react with specific gangliosides or are directed against components of myelin or proteins located at the node of Ranvier [28, 38, 49]. Leukocytes, such as monocytes or $\mathrm{T}$ and $\mathrm{B}$ lymphocytes, can penetrate the previously permeabilized blood-nerve barrier to enter the peripheral nerve through a process mediated by chemokines, cellular adhesion molecules and metalloproteinases, where they can lead to myelin destruction or axonal damage [38].

In AIDP, a molecular mimicry mechanism is presumed between the antigen and gangliosides. Data suggests that the autoantibodies in AIDP are directed against the surface of Schwann cells and are in the specific regions after binding and then fix the complement that is derived from local macrophages or from serum complement proteins, which lead to macrophagemediated demyelination and complement C3d and C5b-9 deposition that have been observed in sural nerve biopsy on the outer surface of the Schwann cells $[16,28]$.

Different types of antibodies are directed against specific gangliosides and glycolipid complexes and also anti-disialosyl antibodies have been described to be associated with the subtypes of GBS. For example, in the motor phenotype AMAN, anti-GM1, antiGM1b, GD1a and anti-GalNAc0GD1 are found directed against these gangliosides that are located predominantly on the axolemma of the motor nerves $[28,46]$. Other antibodies include GD1b, GD3, GT1b, and GQ1b, and they are also involved in the autoimmune attack $[28,46]$. In the case of the axonal primary impairment these antibodies determines the damage of the nodal axolemma with changes and alterations of de sodium channels, followed by the alteration of paranodal myelin $[8,28]$. This is a process that is mediated by the binding of the antibodies at the nodal regions and activation of the complement and formation of the membrane attack complex and with macrophage invasions in later studies [29, 47]. In patients with Miller Fisher syndrome, anti-GQ1b which are well represented in the cranial nerves and innervate extraocular muscles, along with anti-GT1a antibodies have been described. Furthermore, the presence of anti GM1 and GD1 was also associated with the ASMAN phenotype [28].

The treatments with proven efficacy in GBS were therapeutic plasma exchange and IVIg [24, 40]. Clinical trials have shown similar efficacy for IVIg administration and therapeutic plasma exchange in GBS with regards to the improvement in motor deficits, sensory impairment, and cranial nerve dysfunction [24, 27]. However, therapeutic plasma exchange should be performed with caution in patients with autonomic nervous system involvement and hemodynamic instability which are predisposed to hypotension due to the high plasma volume changed [12, 49].

IVIg contain IgG molecule and smaller quantities of $\operatorname{IgM}$ and $\operatorname{IgA}$ antibodies and all are obtained from a pool of plasma which are collected from 5000 - 10000 healthy donors, all of whom must be screened for active infectious diseases. There are viral and prion inactivation methods (pasteurization, acid $\mathrm{pH}$, nanofiltration, solvent-detergent treatment) that significantly reduce the risk of infectious transmission $[6,56]$. The IgG molecule is present in monomeric form, but can be also found as dimers and polymers with two important parts: the Fc fraction and the antigen binding region [17]. IVIg competes with APC and reduces the activation of self-reactive $\mathrm{T}$ cells that release cytokines, such as IFN- $\gamma$, IL-4, IL-5, IL-6 with a pro-inflammatory effect, thus exerting an antiinflammatory effect. This reduces the activation and proliferation of B-lymphocytes that play a role in the production of autoantibodies and through the action on $\mathrm{Fc}-\gamma$ receptors increase the pathogenic IgG catabolism in the circulation with the reduction of autoantibodies [2, 10, 17]. IVIg disrupts complement cascade activation and modulates Fc-receptor mediated activity of immune cells with a down-regulation of macrophage activity, reduction of inflammatory cytokine levels and cell adhesion molecules, thereby limiting the passage of autoimmune cells through the bloodnerve barrier [17, 33-35, 39, 43].

AIDP was the most frequent phenotype in our study (77\%), a finding similar to other reports in North America and Europe [15] and we noticed male predominance in our patients $(61 \%)$ as other authors reported [48, 49]. 
Numerous factors were considered for the prediction of the clinical course of GBS, such as patient age, potentials triggers (infections, vaccines and surgical procedures), disability score, and it was observed that the older age, the presence of diarrhoea and the marked disability at admission were correlated with a negative prognosis regarding neurologic recovery [51]. An association between GBS and influenza vaccine was also demonstrated by a meta-analysis published in 2015 (relative risk 1.41) [28, 31]. The higher risk of developing GBS after influenza infections, however, supports the beneficial role of vaccines [20, 37]. We were unable to find in our study a correlation between the severity of MRC sum score and the presence of the etiological factors (infections, vaccines, surgery) but it is to be noted that we did not perform a statistical analysis focused on each risk factor separately, which could have led to better accuracy ( $p>0.05$, Table V). When comparing the group of patients with IVIg treatment with those with corticosteroids, a significant correlation with the etiological factors was observed in the more affected group receiving IVIg ( $p=0.04$, Table II). A separate analysis of the patients receiving treatment with IVIg showed that their age was statistically significantly lower compared to patients receiving corticosteroids $(\mathrm{p}=0.013)$ in our group of patients. After analysing the entire group of patients with GBS, we were still unable to find a significant correlation between patient age and GBS phenotype (AIDP, AMAN, ASMAN) ( $p>0.05)$ and also did not find significant correlations with cranial nerve involvement, essential hypertension, diabetes mellitus, time from onset to admission, increased protein level in CSF, MRC sum score at admission and at discharge, length of hospitalization or death (Table II). The incidence of GBS increases with age, becoming more common in the $5^{\text {th }}$ decade in western countries [1] but all age groups can be affected [45]. This can be seen in the case of India, where it commonly occurs at a younger age $[14,26]$. The average age of our patients is around 50 years like the data reported in western countries.

Through performing statistical correlations between MRC sum score at admission and MRC sum score at discharge for all the patients (Table IV) and applying Student Pair tests, a statistically significant difference with improvement between the moment of admission and discharge of $\mathrm{p}=0.0001$ was found. Evaluating MRC sum score at admission and at discharge, an inverse correlation was observed (rho $=-0.247 \mathrm{MRC}$ sum score at admission/rho $=-0.253$ MRC sum score at discharge) and statistically significant $(\mathrm{p}=0.016$ MRC sum score at admission/p $=0.013$ MRC sum score at discharge) only with the length of hospitalization its duration being lower if the MRC sum score was higher, which is normal for the clinical evolution, with a more severely affected patient requiring a longer hospitalization period. The evaluation of MRC sum score at admission and at discharge in patients receiving IVIg treatment evidenced an inverse correlation (rho = -0.296 MRC sum score at admission) and was statistically significant $(\mathrm{p}=0.037 \mathrm{MRC}$ sum score at admission) only with the length of hospitalization, with its duration being lower if the MRC sum score is higher at admission.

Recently, a study by Japanese researchers that was published in 2017 evaluated the chance to develop respiratory failure and found that it was associated with increased motor deficiency; the time elapsed between the onset of symptoms and admission and the presence of cranial nerve damage [54]. We found in our study, as in the previous mentioned one, that by applying the Student test for all the patients, a statistically significant correlation was found between the severity of motor deficit assessed by the MRC sum score at admission/at discharge with the occurrence of respiratory insufficiency $(\mathrm{p}=0.001 / \mathrm{p}=0.0001)$ and the need for mechanical ventilation $(\mathrm{p}=0.001 / 0.001)$. In addition the mean values of MRC sum score at discharge were higher in the absence of respiratory insufficiency and the need for mechanical ventilation. MRC sum score at discharge was significant correlated with the involvement of the cranial nerves $(p=0.034)$, and the mean values of MRC sum score at discharge were also higher in the absence of cranial nerve involvement. When we separately analysed the group of patients receiving IVIg treatment by applying Student test, a statistically significant correlation was found between the severity of motor deficit assessed by the MRC sum score at admission/at discharge and the occurrence of respiratory insufficiency $(\mathrm{p}=0.01 /$ $0.001)$, the need for mechanical ventilation ( $p=0.009$ / 0.0001 ) and the complications caused by superimposed infections ( $p=0.007 / 0.002)$ the mean values of MRC sum score at admission and at discharge is higher in the absence of respiratory insufficiency, along with the need for mechanical ventilation and lack of superimposed infections. The MRC sum score improved significantly statistically when we analysed all the patients with GBS $(\mathrm{p}=0.0001)$ and the patients that received IVIg treatment $(p=0.0001)$ between the moment of admission and the moment of discharge.

A systematic review of the Cochrane Database regarding the corticosteroids for GBS concluded that corticosteroids did not significantly hasten neurologic recovery in GBS and do not affect the long term prognosis. In addition, there is moderate data that the association between corticosteroids and IVIg would speed up recovery. With the exception of increased glycaemic levels, no significant side effects of corticosteroids were observed [22]. Patients in our study who received corticosteroids and supportive treatment had milder neurological impairments and no unfavourable evolution was observed when compared with the group treated with IVIg. Patients with more severe neurological 
impairment received IVIg treatment and it thus explained the lower MRC sum score in the IVIg group.

Of particular importance is the treatment and supportive measures of GBS patients which consists in the prevention and treatment of superimposed infections due to immobilization and respiratory dysfunction, the prevention of deep vein thrombosis, the monitoring of autonomic nervous system dysfunction, and the treatment of associated pain. In the case of aggravation, the transfers in the intensive care unit may need to be handled with a multi-disciplinary approach $[25$, 49]. As previously shown, the lack of superimposed infections was correlated with a better evolution of mean MRC sum score at admission and at discharge in our study.

There are no different therapeutic indications for GBS phenotypes. MRC sum score at discharge was improved for all patients with GBS and with regards to the distribution of GBS phenotypes; there were no significant differences between patients treated with IVIg and patients treated with corticosteroids ( $p$ > $0.05)$.

As for mild cases of GBS that do not endanger the patient's life and are not accompanied by a major motor weakness/deficit, there are discussions about the clinical benefit of IVIg and further clinical trials are needed to assess the efficacy of IVIg in these forms [21, 24, 28]. In addition, we also have to take into account the cost/benefit ratio, especially in a country that has financial problems regarding the health system. As shown in Table IV, all patients who had respiratory insufficiency and most patients with autonomic nervous system involvement received IVIg in our clinic, the alternative treatment being reserved for the cases with milder evolution that did not have major motor deficits.

The disease is potentially life-threatening, with a poor outcome in many cases, even with the best medical care available [30]. Generally, 2 - 10\% of patients may die, $20 \%$ may be bedridden at six months, and $60-80 \%$ of patients with GBS can walk independently six months after the disease onset while a number of them will still suffer some residual symptoms like pain and severe fatigue $[30,49,52]$. Some patients may present relapses, and this amounts to $2-5 \%$ of the cases $[30,42]$. The mortality rate in our study is $3 \%$, which is in the range reported in the medical literature, and all of those severe affected received treatment with IVIg that is in accordance with the guidelines.

Our study has several limitations, such as not including a large number of patients, how they were followed only for the period of hospitalization, and the way in which we access data occurred retrospectively limited our analysis. On the other hand, it also is among the few studies regarding GBS in Romanian patients, with the previous one assessing the autonomic dysfunction in AIDP being published by Cuciureanu in 2004
[9]. This is the first one in Romanian patients to evaluate the characteristics of the patients, the distribution of phenotypic variants, the existence of triggers factors, and the evolution of motor deficit in the presence of different types of medications. Further studies would be necessary to evaluate long term prognosis and the treatment for specific subgroups of these patients.

\section{Conclusions}

IVIg remain an important therapeutic resource in the treatment of cases with severe neurological damage and if administered early, the outcome would be better due to the interruption of the pathophysiological mechanisms underlying the alteration of the peripheral nerve in GBS through its anti-inflammatory effect. The mortality rate in the hospital was $3 \%$ and the majority of our patients had good functional evolution.

\section{Conflict of interest}

The authors declare no conflict of interest.

\section{References}

1. Alter M, The epidemiology of Guillain-Barré syndrome. Ann Neurol., 1990; 27(S1): S7-S12.

2. Bayry J, Lacroix-Desmazes S, Kazatchkine MD, Kaveri SV, Monoclonal antibody and intravenous immunoglobulin therapy for rheumatic diseases: rationale and mechanisms of action. Nat Clin Pract Rheumatol., 2007; 3(5): 262-272.

3. Bălaşa R, Maier S, Moțăţăianu A, Bajko Z, Moldovan $\mathrm{O}$, Benedek $\mathrm{E}, \mathrm{A}$ case of fatal acute intermittent porphyria: laboratory diagnosis and pathogenesis considerations. Rev Română Med Lab., 2014; 22(3): 325-333.

4. Bowyer HR, Glover M, Guillain-Barre syndrome: management and treatment options for patients with moderate to severe progression. J Neurosci Nurs., 2010; 42(5): 288-293.

5. Cao-Lormeau VM, Blake A, Mons S, Lastère S, Roche C, Vanhomwegen J, Dub T, Baudouin L, Teissier A, Larre P, Vial AL, Decam C, Choumet V, Halstead SK, Willison HJ, Musset L, Manuguerra JC, Despres P, Fournier E, Mallet HP, Musso D, Fontanet A, Neil J, Ghawché F, Guillain-Barré Syndrome outbreak associated with Zika virus infection in French Polynesia: a case-control study. Lancet, 2016; 387(10027): 1531-1539.

6. Chaigne B, Mouthon L, Mechanisms of action of intravenous immunoglobulin. Transfusion Apheresis Sci., 2017; 56(1): 45-49.

7. Choudary JR, Alladi S, Mridula KR, Oddu DB, Rao MV, Hemanth C, Clinical Outcome of GuillainBarre Syndrome with various treatment methods and cost effectiveness: A Study from tertiary care centre in South India. Neurology Asia, 2014; 19(3): 263-270.

8. Clark AJ, Kaller MS, Galino J, Willison HJ, Rinaldi S, Bennett DLH, Co-cultures with stem cell-derived 
FARMACIA, 2020, Vol. 68, 3

human sensory neurons reveal regulators of peripheral myelination. Brain, 2017; 140(4):898-913.

9. Cuciureanu D, Prodan R, Autonomic dysfunction in acute inflammatory demyelinating polyneuropathy. Rev Med Chir Soc Med Nat Iasi, 2004; 108(1): 155-158.

10. Ephrem A, Misra N, Hassan G, Dasgupta S, Delignat S, Van Huyen JP, Chamat S, Prost F, Lacroix-Desmazes S, Kavery SV, Kazatchkine MD, Immunomodulation of autoimmune and inflammatory diseases with intravenous immunoglobulin. Clin Exp Med., 2005; 5(4): 135-140.

11. Fokke C, van den Berg B, Drenthen J, Walgaard C, van Doorn PA, Jacobs BC, Diagnosis of GuillainBarré syndrome and validation of Brighton criteria. Brain, 2014; 137(1): 33-43.

12. Gajjar, MD, Shah SD, Shah MC, Bhatnagar NM, Soni S, Patel T, Efficacy and Cost Effectiveness of Therapeutic Plasma Exchange in patient of Guillain-Barre Syndrome A Prospective study. Southeast Asian J Case Rep Rev., 2013; 2(4): 218-228.

13. Guillain G, Barré JA, Strohl A, Sur un syndrome de radiculonévrite avec hyper-albuminose du liquide céphalo-tachidien sans réaction cellulaire. Remarques sur les caractères cliniques et graphiques des réflexes tendineux. Bul Mém Soc Med Hôp Paris, 1916; 40: $1462-1470$

14. Gupta SK, Taly AB, Suresh TG, Rao S, Nagaraja D, Acute idiopathic axonal neuropathy (AIAN) - a clinical and electrophysiology observation. Acta Neurol Scand., 1994; 89(3): 220-224.

15. Hadden RD, Cornblath DR, Hughes RA, Zielasek J, Hartung HP, Toyka KV, Swan AV, Electrophysiological classification of Guillain-Barré syndrome: clinical associations and outcome. Plasma exchange/Sandoglobulin Guillain-Barre syndrome trial group. Ann Neurol., 1998; 44(5):780-788.

16. Hafer-Macko CE, Sheikh KA, Li CY, Ho TW, Cornblath DR, McKhann GM, Asbury AK, Griffin JW, Immune attack on the Schwann cell surface in acute inflammatory demyelinating polyneuropathy. Ann Neurol., 1996; 39(5): 625-635.

17. Hartung HP, Advances in the understanding of the mechanism of action of IVIg. J Neurol., 2008; 255(S3): 3-6.

18. Head VA, Wakerley BR, Guillain-Barre syndrome in general practice: clinical features suggestive of early diagnosis. Br J Gen Pract., 2016; 66(645): 218-219.

19. Ho TW, Mishu B, Li CY, Gao CY, Cornblath DR, Griffin JW, Asbury AK, Blaser MJ, McKhann GM, Guillain-Barré syndrome in northern China. Relationship to Campylobacter jejuni infection and antiglycolipid antibodies. Brain, 1995; 118(Pt 3): 597-605.

20. Hocker S, Nagarajan E, Rubin M, Wijdicks EFM, Clinical factors associated with Guillain-Barré syndrome following surgery. Neurol Clin Pract., 2018; 8(3): 201-206.

21. Hughes R, Treatment of peripheral nerve disorders. Curr Opin Neurol., 2005; 18(5): 554-556

22. Hughes RA, Brassington R, Gunn AA, van Doorn PA, Corticosteroids for Guillain-Barré syndrome. Cochrane Database Syst Rev., 2016; 10: CD001446.
23. Hughes RA, Cornblath DR, Guillain-Barre syndrome. Lancet, 2005; 366(9497): 1653-1666

24. Hughes RA, Swan AV, van Doorn PA, Intravenous immunoglobulin for Guillain-Barré syndrome. Cochrane Database Syst Rev., 2012; 7: CD002063.

25. Hughes RA, Wijdicks EF, Benson E, Cornblath DR, Hahn AF, Meythaler JM, Sladky JT, Barohn RJ, Stevens JC, Multidisciplinary Consensus Group, Supportive care for patients with Guillain-Barré syndrome. Arch Neurol., 2005; 62(8); 1194-1198.

26. Kaur U, Chopra JS, Prabhakar S, Radhakrishnan K, Rana S, Guillain-Barré syndrome - a clinical electrophysiological and biochemical study. Acta Neurol Scand., 1986; 73(4): 394-402.

27. Kieseier BC, Kiefer R, Gold R, Hemmer B, Willison HJ, Hartung HP, Advances in understanding and treatment of immune-mediated disorders of the peripheral nervous system. Muscle Nerve, 2004; 30(2): 131-156.

28. Kieseier BC, Mathey EK, Sommer C, Hartung HP, Immune-mediated neuropathies. Nat Rev Dis Primers., 2018; 4(1): 1-23.

29. Kuwabara S, Yuki N, Axonal Guillain-Barré syndrome: concepts and controversies. Lancet Neurol., 2013; 12(12): 1180-1188.

30. Leonhard SE, Mandarakas MR, Gondim FAA, Bateman K, Ferreira MLB, Cornblath DR, van Doorn PA, Dourado ME, Hughes RAC, Islam B, Kusunoki S, Pardo CA, Reisin R, Sejvar JJ, Shahrizaila N, Soares C, Umapathi T, Wang Y, Yiu EM, Willison HJ, Jacobs BC, Diagnosis and management of Guillain-Barré syndrome in ten steps. Nat Rev Neurol., 2019; 15(11): 671-683.

31. Martín Arias LH, Sanz R, Sáinz M, Treceño C, Carvajal A, Guillain-Barré syndrome and influenza vaccines: A meta-analysis. Vaccine, 2015; 33(31): 3773-3778.

32. Nagarajan E, Rubin M, Wijdicks EFM., Hocker SE, Guillain-Barré syndrome after surgical procedures. Neurol Clin Pract., 2016; 2016: 1-9.

33. Navolan D, Sas I, Terness P, Are IgG-anti-Fab2r and IgG-anti-Hinge antibodies active constituents of intravenous immunoglobulin?. Farmacia, 2015; 63(5): 647-651.

34. Nimmerjahn F, Ravetch JV, Anti-inflammatory actions of intravenous immunoglobulin. Annu Rev Immunol., 2008; 26(1): 513-533.

35. Nimmerjahn F, Ravetch JV, The antiinflammatory activity of IgG: the intravenous IgG paradox. $J$ Exp Med., 2007; 204(1): 11-15.

36. Orlikowski D, Porcher R, Sivadon-Tardy V, Raphaël JC, Durand MC, Sharshar T, Roussi J, Caudie C, Annane D, Rozenberg F, Leruez-Ville M, Gaillard JL, Gault E, Guillain-Barré syndrome following primary cytomegalovirus infection: a prospective cohort study. Clin Infect Dis., 2011; 52(7): 837-844.

37. Poland GA, Jacobsen SJ, Influenza vaccine, GuillainBarré syndrome, and chasing zero. Vaccine, 2012; 30(40): 5801-5803.

38. Rajabally YA, Stettner M, Kieseier BC, Hartung, HP, Malik RA, CIDP and other inflammatory neuropathes in diabetes - diagnosis and management. Nature Reviews Neurology, 2017; 13(10): 599-611.

39. Raju R, Dalakas MC, Gene expression profile in the muscles of patients with inflammatory myopathies: 
effect of therapy with IVIg and biological validation of clinically relevant genes. Brain, 2005; 128(8): 1887-1896.

40. Raphael JC, Chevret S, Hughes RA, Annane D, Plasma exchange for Guillain-Barré syndrome. Cochrane Database Syst Rev., 2012; 7: CD001798.

41. Rocha MS, Brucki SM, Carvalho AA, Lima UW, Epidemiologic features of Guillain-Barré syndrome in São Paulo, Brazil. Arq Neuropsiquiatr., 2004; 62(1): 33-37.

42. Ruts L, Drenthen J, Jacobs BC, van Doorn PA, Dutch GBS Study Group, Distinguishing acute-onset CIDP from fluctuating Guillain-Barre syndrome: a prospective study. Neurology, 2010; 74(21): 1680-1686.

43. Samuelsson A, Towers TL, Ravetch JV, Anti-inflammatory activity of IVIG mediated through the inhibitory Fc receptor. Science, 2001; 291(5503): 484-486.

44. Schonberger LB, Bregman DJ, Sullivan-Bolyai JZ, Keenlyside RA, Ziegler DW, Retailliau HF, Eddins DL, Bryan JA, Guillain-Barre syndrome following vaccination in the National Influenza Immunization Program, United States, 1976-1977. Am J Epidemiol., 1979; 110(2): 105-123.

45. Sejvar JJ, Baughman AL, Wise M, Morgan OW, Population incidence of Guillain-Barré syndrome: a systematic review and meta-analysis. Neuroepidemiology, 2011; 36(2): 123-133.

46. Sheikh KA, Deerinck TJ, Ellisman MH, Griffin JW, The distribution of ganglioside-like moieties in peripheral nerves. Brain, 1999; 122(Pt 3): 449-460.

47. Susuki K, Rasband MN, Tohyama K, Koibuchi K, Okamoto S, Funakoshi K, Hirata K, Baba H, Yuki N, Anti-GM1 antibodies cause complement-mediated disruption of sodium channel clusters in peripheral motor nerve fibers. J Neurosci., 2007; 27(15): 3956-3967.
48. Van den Berg B, Bunschoten C, van Doorn PA, Jacobs BC, Mortality in Guillain-Barré syndrome. Neurology, 2013; 80(18): 1650-1654.

49. Van den Berg B, Walgaard C, Drenthen J, Fokke C, Jacobs BC, van Doorn PA, Guillain-Barré syndrome: pathogenesis, diagnosis, treatment and prognosis. Nat Rev Neurol., 2014; 10(8): 469-482.

50. Van Doorn PA, Ruts L, Jacobs BC, Clinical features, pathogenesis, and treatment of Guillan Barre syndrome. Lancet Neurol., 2008; 7(10): 939-950.

51. Van Koningsveld R, Steyerberg EW, Hughes RA, Swan AV, van Doorn PA, Jacobs BC, A clinical prognostic scoring system for Guillain-Barré syndrome. Lancet Neurol., 2007; 6(7): 589-594.

52. Verboon C, van Doorn PA, Jacobs BC, Treatment dilemmas in Guillain-Barré syndrome. J Neurol Neurosurg Psychiatry, 2017; 88(4): 346-352.

53. Wajih Ullah M, Qaseem A, Amray A, Post Vaccination Guillain Barre Syndrome: A Case Report. Cureus, 2018; 10(4): 1-3.

54. Walgaard C, Lingsma HF, Ruts L, Drenthen J, van Koningsveld R, Garssen MJ, van Doorn PA, Steyerberg EW, Jacobs BC, Prediction of respiratory insufficiency in Guillain-Barré syndrome. Ann Neurol., 2010; 67(6): 781-787.

55. Winer JB, Hughes RA, Osmond C, A prospective study of acute idiopathic neuropathy. I. Clinical features and their prognostic value. J Neurol Neurosurg Psychiatry, 1988; 51(5): 605-612.

56. World Health Organization, Recommendations for the production, control and regulation of human plasma for fractionation. WHO Tech Rep Ser., 2007; 941(Annex 4): 189-264. 